\title{
Duration of Nursing Care in Patients with Hip Fractures
}

1 Tihana Harapin Savić

1 Valentina Košćak

${ }^{1}$ University Hospital Dubrava, Zagreb, Croatia

Article received: 29.07.2017.

Article accepted: 07.12.2018.

DOI: $10.24141 / 2 / 3 / 1 / 6$

Author for correspondence:

Valentina Košćak

Avenija Gojka Šuška 6, Zagreb, Croatia

Phone:+38512902415

E-mail: vkoscak@kbd.hr

Keywords: nursing care, hip fracture, nurse

\section{Abstract}

The research regarding the duration of nursing care in patients with hip fractures was conducted at the Traumatology and Orthopedic Institute of the University Hospital Dubrava in a period of 4 months. The research was conducted on 59 patients with a diagnosis of a broken hip, that have undergone surgery. The goal of this research was to determine the differences in the duration of nursing care due to age, gender, comorbidities and postoperative day. Statistical significance in all measurements was reduced to $p<0.05$. The research shows connection between patient age and the duration of nursing care. The presence of comorbidity also prolongs the duration of nursing care. Shorter duration of nursing care was determined in women compared to men in all age groups, but it wasn't of statistical significance. 


\section{Introduction}

Hip fractures represent a serious physical injury that can have many complications and can increase the risk of mortality in elderly people. These types of fractures are common in elderly people, because, with ageing, the firmness, density and structure quality of the thigh bone deteriorate making it less resistant to trauma. It is because of the weakened bones, or osteoporosis and poor coordination, vision problems and different side effects from medication that elderly people are more prone to falling, and that is why hip fractures are most common above the age of 65 (1).

With the increase in the elderly population, longer life expectancy and greater traffic speed, the number of hip fracture incidents is increasing as well. The assessment is that by the year 2050 the number of hip fractures will go up to 6.26 million per year on a global scale. The frequency rate of hip fractures in Croatia is 4.7 per 1000 residents in the 65 and over age group (2).

Hip fracture mortality in the first year after the fracture is between 12 and $20 \%$ and there is almost no difference in countries with a very different degree of health standard (3).

Hip fractures in younger patients are most commonly caused by a strong direct force to the large trochanter, mainly by direct impact to the hip. In elderly people, a much weaker force is needed to cause a hip fracture, such as falling from a height or from an upright position. Hip fractures can be induced by pathological bone changes caused by tumours or metastases.

The fracture diagnosis is determined by taking the patient's history, and by physical examination. The type of fracture and indications for conservative treatment or surgery are determined by radiographic imaging (X-ray). If a fracture cannot be precisely determined by $\mathrm{X}$-ray, and there is clinical doubt of its existence, it is necessary to perform a computerized tomography scan (CT).

Treatment methods depend on the type of fracture, patient age and vitality, comorbidities and life expectancy. Hip fractures are mainly treated surgically. Conservative treatments are intended for a small number of patients whose health condition is so bad that surgery is contraindicated by an anesthesiologist because the percentage of complications and early mortality are extremely high.

Surgical procedures for the treatment of fracture of the neck of the thorax include closed or open repositioning and internal fixation (cannulated bolts, dynamic neckline of the thigh bone, DHS, partial or total hip endoprosthesis) (4). All of the different treatment methods have one aim and that is to achieve the best possible functional result.

Today's stabilisation operational methods allow early mobilisation of adjacent joints, faster recovery to full mobility, and in some cases, the possibility of an even sooner physical exertion of the operated area. After the surgery, it is necessary to start the rehabilitation program as soon as possible. Every patient in the rehabilitation process has to have an individual approach that is adjusted to his or her needs and the type of surgical procedure performed. It is important to encourage the patients to exercise and get on their feet as soon as possible so that the risk of postoperative complications would be as low as possible. The goal of this research was to determine the differences in the duration of nursing care considering gender, age, comorbidities and postoperative day.

\section{Methods}

The research was carried out at the University Hospital Dubrava, Traumatology and Orthopedics Institute in the period from December $1^{\text {st }} 2014$ until March $31^{\text {st }} 2015$.

The research was conducted at the Traumatology Department on a sample of 59 patients who were diagnosed with hip fracture that had to be treated surgically. The research was conducted on 11 male and 48 female patients with an average age of 77 years and 2 months.

Upon patient arrival at the Traumatology and Orthopaedics Institute, a socio-demographic survey, made for the purpose of this research, was conducted (gender, age, comorbidities). 
The survey gathered information on a daily basis which gave an insight into nursing care processes. Oral consentwas given by the patients or a family member to conduct the survey. The collected data were linked to the date of surgery, type of operation and redone drainage, nursing care, therapy (application of infusion and transfusion, application of urinary catheter, application of splint and number of days of operative wound care) and complications. Data related to the duration of nursing care in postoperative days were obtained by inspecting the nursing documentation of the performed procedures in a way that sums up the duration of nursing care of all the procedures performed in minutes, through 24 hours.

STATISTICA 12.0. was used for statistical processing. Normality of distribution of continuous variables was verified by using the Shapiro-Wilks test, and homogeneity of variance by using the Levene test. The Ttest was used to determine the difference between the mean values of the variables between the two groups, and the variance analysis and the NewmanKeuls test were used to determine the difference between more than two groups. Before the above mentioned test were used, variables which deviated from the normal distribution were reduced to the same distribution by using a logarithm. Linear regression analysis was used to determine the possible correlation between postoperative time and duration of nursing care, and multiple regression analysis and general regression models were used to determine the influence of other predictor variables (sex, age, comorbidity). Statistical significance in all measurements was reduced to $p<0.05$.

\section{Results}

Age of the patients ranges from 38 to 91 (77.2 \pm 11.4). Of the 59 respondents, $48(81.4 \%)$ were women and 11 were men (18.6\%).

The number of days required for recovery (Table 1 ) ranged from 0 to $19(4.9 \pm 3.5)$ and the duration of nursing care from 0 to 120 minutes $(75 \pm 19.2)$. If the duration of nursing care is grouped depending on the postoperative day (Table 2 ), it shows a decrease from zero $(96.4 \pm 17.4)$ to the $11^{\text {th }}$ day $(51.8 \pm 14.9)$, after which there is a slight increase up to the $15^{\text {th }}$ day. The variance analysis confirmed a statistically significant difference in the duration of nursing care between postoperative days $(F=4.48 ; p=0.0006)$. The Newman-Keuls test confirmed that this difference was statistically significant between day zero and the $8^{\text {th }}, 9^{\text {th }}, 10^{\text {th }}, 11^{\text {th }}$ and $12^{\text {th }}$ day, and between the first and the $10^{\text {th }}, 11^{\text {th }}$ and $12^{\text {th }}$ day, while between the other days there were no statistically significant differences in the duration of nursing care.

The value of the Pearson correlation coefficient showed statistically significant, positive correlation $(r=0.46)$ between the duration of nursing care in minutes and the age of the patient, showing when the age of the patient grows, duration of nursing care increase.

The value of the Pearson correlation coefficient showed a good statistically significant, negative correlation $(r=-0.63)$ between the duration of nursing care and the postoperative day, indicating a significant reduction of the duration of nursing care with the increase of postoperative time.

The results of multiple regression analysis (Table 3) show that two predictors, of the four introduced, are statistically significant - the age and presence of comorbidity. All four predictors explain a total of $63 \%$ of the variance of the duration of nursing care. It is longer for the patients who are older and have comorbidities, age has a greater influence on the duration of nursing care.

\begin{tabular}{|c|c|c|c|c|c|c|c|c|}
\hline \multirow[b]{2}{*}{$\mathbf{N}$} & \multicolumn{4}{|c|}{ Postoperative day } & \multicolumn{4}{|c|}{ Duration of nursing care } \\
\hline & $\overline{\mathbf{x}}$ & SD & Minimum & Maximum & $\bar{x}$ & SD & Minimum & Maximum \\
\hline 59 & 4.9 & 3.5 & 0 & 19 & 75.0 & 19.2 & 0 & 120 \\
\hline
\end{tabular}


Table 2. Duration of nursing care (expressed in minutes) depending on the postoperative day

\begin{tabular}{|c|c|c|c|c|}
\hline \multirow[b]{2}{*}{ Postoperative day } & \multicolumn{4}{|c|}{ Statistical parameter } \\
\hline & $\overline{\mathbf{x}}$ & SD & Minimum & Maximum \\
\hline 0 & 96.4 & 17.4 & 0 & 120 \\
\hline 1 & 91.5 & 16.8 & 0 & 120 \\
\hline 2 & 85.9 & 15.9 & 0 & 110 \\
\hline 3 & 83.3 & 12.2 & 45 & 120 \\
\hline 4 & 77.1 & 13.1 & 35 & 120 \\
\hline 5 & 73.1 & 12.1 & 50 & 110 \\
\hline 6 & 67.7 & 12.9 & 40 & 100 \\
\hline 7 & 63.9 & 11.9 & 35 & 90 \\
\hline 8 & 60.4 & 11.1 & 40 & 80 \\
\hline 9 & 57.4 & 12.5 & 30 & 75 \\
\hline 10 & 54.5 & 14.0 & 30 & 70 \\
\hline 11 & 51.8 & 14.9 & 30 & 70 \\
\hline 12 & 54.4 & 19.9 & 30 & 90 \\
\hline 13 & 58.3 & 21.4 & 30 & 90 \\
\hline 14 & 63.8 & 22.9 & 35 & 90 \\
\hline 15 & 80.0 & 14.1 & 70 & 90 \\
\hline 16 & 70.0 & 0.0 & 70 & 70 \\
\hline 17 & 70.0 & 0.0 & 70 & 70 \\
\hline 18 & 70.0 & 0.0 & 70 & 70 \\
\hline 19 & 70.0 & 0.0 & 70 & 70 \\
\hline All & 75.0 & 19.2 & 0 & 120 \\
\hline
\end{tabular}

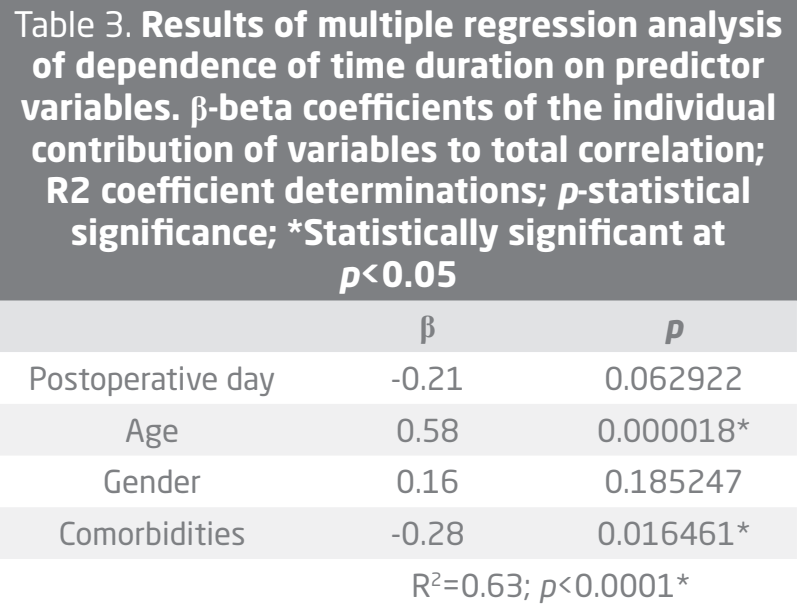

Similar results were obtained with the general regression model showed in the Pareto diagram (Picture 1), where it is shown that the age and the comorbidities are significantly associated with the duration of nursing care.

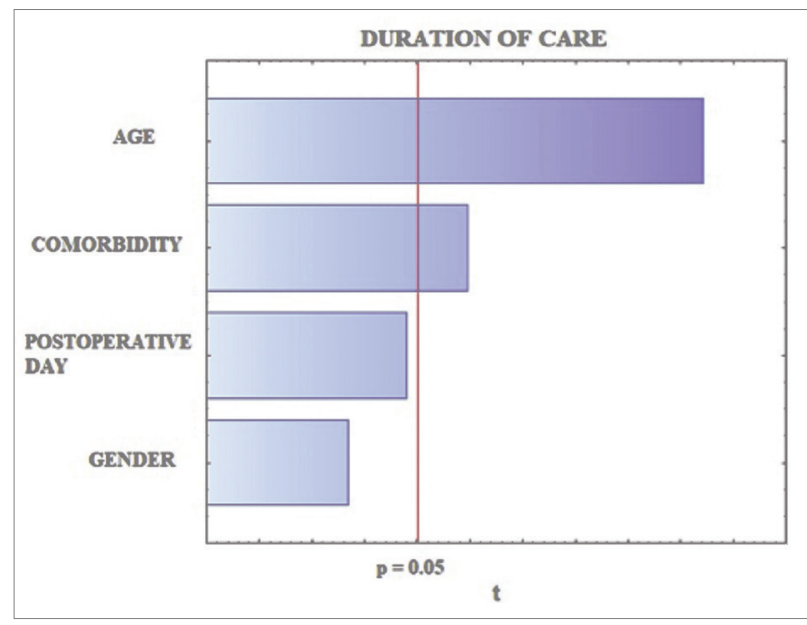

Figure 1 . The results of a multiple regression model expressed in the form of Pareto Diagram of dependence of duration of nursing care on predictor variables 
Table 4. Basic statistical parameters and t-test results for the duration of nursing care with regard to gender of respondents

\begin{tabular}{ccccccc} 
& $\mathbf{N}_{\mathbf{W}}$ & $\mathbf{N}_{\mathbf{M}}$ & $\mathbf{X}_{\mathbf{W}} \pm \mathbf{S D}_{\mathbf{W}}$ & $\mathbf{X}_{\mathbf{M}} \pm \mathbf{S D}_{\mathbf{M}}$ & $\mathbf{t}$ & $\boldsymbol{P}$ \\
\hline Duration of care (min.) & 48 & 11 & $75.76 \pm 10.2$ & $74.54 \pm 16.1$ & 0.31 & 0.7524
\end{tabular}

\begin{tabular}{|c|c|c|c|}
\hline \multirow{2}{*}{ Comorbidities } & \multirow{2}{*}{$\mathbf{N}$} & \multicolumn{2}{|c|}{ Duration of nursing care } \\
\hline & & $\overline{\mathbf{x}}$ & SD \\
\hline YES & 44 & 77.3 & 11.3 \\
\hline NO & 14 & 70.2 & 10.7 \\
\hline All & 58 & 75.6 & 11.5 \\
\hline
\end{tabular}

It can be seen (Table 4) from the results that there are no statistically significant differences in the duration of care considering to the gender of respondents.

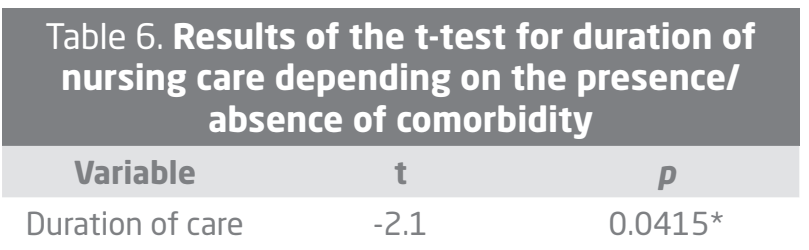

From Table 5 it is apparent that those with comorbidities require longer treatment time $(77.3 \pm 11.3)$ than those with no comorbidity $(70.2 \pm 10.7)$. T-test (Table 6) confirmed that the difference was statistically significant $(p=0.0415)$.

\section{Discussion}

Today's modern lifestyle and the increased ageing of the population cause common chronic diseases. Most of the patients above 65 years of age have one or more somatic diseases. Such associated diseases have a big impact on the nursing care process: they require more time and effort, knowledge, experience and proficiency.

One or more comorbidities are present in 44 patients (76.3\%) covered by this study. Among the comorbidities, cardiovascular disease is present in 39 (66.1\%) patients, which is expected because of the greater age of the patient. Arterial hypertension is present in 28 (47.5\%) patients.

Among other comorbidities, diabetes is present in 17 (28.8\%) patients and other comorbidities are present in 23 (39\%) patients. Respiratory diseases and alcoholism are present in three patients, and nephrologic and malignant diseases in five patients.

In a similar research, Vukamanović et al. state that almost $80 \%$ of patients have had associated diseases, and the most common were cardiovascular diseases, neurological diseases and diabetes mellitus, as is the case in this research. In their research, most of the rehabilitated patients (81) had associated diseases, and only 22 of them did not have any comorbidities. A large number of patients had a comorbidity, almost $80 \%$ (CV, neurological, endocrinological) (5).

Somewhat different results are described in the paper by Grubor et al. Long-term diseases were noticed in 51 (50\%) patients on admission. The most common were high blood pressure and heart problems in $39(38 \%)$ patients, diabetes mellitus in $7(6 \%)$ patients, renal insufficiency in $2(1.9 \%)$ patients, and osteoporosis in 51(50\%) patient (6).

The results of this research have shown that the duration of nursing care has significant interindividual differences. Generally speaking, it decreases with the increase of postoperative time, and increases with the age of both sexes.

Similar research regarding duration of nursing care in patients with hip fractures were not carried out so 
the results could not have been compared. However, these results are expected. It can be assumed that younger patients will recover more quickly in relation to the elderly, they will be better at following instructions related to performing nursing care procedures, and will be able to perform more self-care activities without the assistance of nurses.

This research has some limitations that are related to the research plan, such as the absence of a control group that would enable verification of the obtained results. Another limitation is the fact that the data was collected throughout the whole day which means that it was collected by different people, and that could have led to mistakes while entering data.

Even though this research was conducted over a period of 4 months and the sample size was relatively large (59 patients), it is possible that a full year of research would result in more meaningful data.

\section{Conclusion}

The results of the research have shown that the duration of nursing care has significant interindividual differences.

Generally speaking, it decreases with the increase in postoperative time, and increases with the age of both sexes. The age of the patient has the greatest contribution to the duration of nursing care. The presence of comorbidity also prolongs the duration of nursing care.

A somewhat shorter duration of nursing care was found in women compared to men in all age groups, but differences were not statistically significant.

Even though the workload of nurses at the Traumatology Department was not the focus of this research, the results speak for themselves, and it is possible to determine the scope of work and the number of nurses needed to perform nursing care procedures based on the number of patients.

\section{References}

1. Mayo Clinic; 1998-2016. Available from: http://www. mayoclinic.org/diseases-conditions/hipfracture/basics/ definition/con-20021033 Accessed: 27.09.2016.

2. Potočki Karačić T, Kopjar B. Učestalost prijeloma kuka u Hrvatskoj u pacijenata u dobi od 65 i više godina. Liječnički vjesnik. 2009;131:9-13.

3. Nastavni zavod za javno zdravstvo Primorsko Goranske županije. Available from: http://www.zzjzpgz.hr/ nzl/29/osteoporoza.htm Accessed: 27.09.2016.

4. Nikolić T, Aljinović $A$, Filipčić $A$, Jakšić $M$, Čop R, Bobek D. Smjernice za rehabilitaciju bolesnika nakon prijeloma u području proksimalnog okrajka bedrene kosti. Fiz rehabil med. 2015;27(3-4):212-236.

5. Vukmanović $M$, Lešić $A$. Rezultati rehabilitacije pacijenata sa prelomom proksimalnog dela femura. Medicinska istraživanja. Available from: http://www.old.med.bg.ac. rs/dloads/medicinska\%20istrazivanja/2\%20med\%20 istr\%202010.pdf

6. Grubor $\mathrm{P}$, Asotić $\mathrm{M}$, Grubor M. Izbor metode liječenja preloma vrata butne kosti osoba starijih od 65 godina. Acta Medica Medianae. 2010;49(3):5-10. 


\section{Sažetak}

Istraživanje o duljini trajanja zdravstvene njege kod bolesnika s prijelomom kuka provedeno je na Zavodu za traumatologiju i ortopediju Kliničke bolnice Dubrava u razdoblju od četiri mjeseca. Uzorak ovog istraživanja činilo je 59 bolesnika s dijagnozom prijeloma kuka u kojih je učinjen kirurški zahvat. Cilj istraživanja bio je utvrditi razlike u duljini trajanja zdravstvene njege kod bolesnika s prijelomom kuka s obzirom na dob, spol, komorbiditete i poslijeoperacijski dan. Statistička značajnost u svim mjerenjima svedena je na $p<0,05$.

Rezultati istraživanja pokazali su da vrijeme trajanja njege pokazuje značajne interindividualne razlike. Generalno gledano smanjuje se s porastom poslijeoperacijskog vremena, a povećava $s$ dobi pacijenata kod oba spola. Dob pacijenta ima najveći utjecaj na vrijeme trajanja njege. Prisutnost komorbiditeta također produžuje vrijeme trajanja njege. Nešto niže vrijeme trajanja njege je utvrđeno kod žena u odnosu na muškarce u svim dobnim skupinama, ali te razlike nisu bile i statistički značajne.

Ključne riječi: zdravstvena njega, prijelom kuka, medicinska sestra 